\title{
An Empirical Study of Dragon Boat Sport on the Construction of College Campus Culture
}

\author{
A Case Study of Wuhan Business University*
}

\author{
Yong Tang \\ The School of Physical Education \\ Wuhan Business University \\ Wuhan, China
}

\author{
Manfu Wang \\ The School of Physical Education \\ Wuhan Business University \\ Wuhan, China
}

\author{
Zhuo Sun** \\ The School of Physical Education \\ Wuhan Business University \\ Wuhan, China \\ **Corresponding Author
}

\begin{abstract}
This topic introduces the concept of college campus culture, analyzes the influence of dragon boat sport on the construction of college campus culture, and understands the development of dragon boat sport in other colleges and universities. Meanwhile, it also studies and formulates questionnaire for students in Wuhan Business University and conducts questionnaire survey on dragon boat sport, and carries out comparative analysis and finds out the shortcomings in the popularization of dragon boat culture and the promotion of dragon boat sport in our university. It proposes that we should make publicity for dragon boat culture, hold campus dragon boat cultural festival and carry out dragon boat themed practice activities relying on dragon boat team and association, and enable students to actively participate in dragon boat competition at all levels, forming a cultural atmosphere of unity, cooperation and mutual help that promotes the spirit of patriotism, inspires historical and cultural studies, and enriches the amateur life, so as to provide practical basis for the development of the dragon boat course teaching in the later period.
\end{abstract}

\section{Keywords—dragon boat; college campus culture; inheritance}

\section{INTRODUCTION}

Dragon boat sport is a mass sport activity with distinctive national features, strong national beliefs and humanistic characteristics. With the increasing attention and participation of college students in dragon boat sport, it is exerting a profound influence on college campus culture. It not only enriches the connotation of campus culture, but also provides new impetus for the construction of campus culture.

*Undergraduate Innovation Training Program of Wuhan Business University; Project No.: 201811654008.

\section{THE CONNOTATION AND CHARACTERISTICS OF College CAMPus CUlture}

\section{A. Connotation}

College campus culture is not a simple combination of university and culture, but an atmosphere created by college students in their work, life and study, including three dimensions: material level, spiritual level and institutional level. In a word, the connotation of college campus culture contains behavioral norms, moral constraints, value orientation, spiritual pillars and life concepts that college students create, follow and share in the long-term education, study, life and practice. The core of campus culture is the common values of college students.

\section{B. Characteristics}

1) Guidance: College campus culture reflects the mainstream value standard of the society. When college students deviate from this standard, the overall cultural atmosphere will play a guiding role. Youth is an important period for the establishment and stabilization of values. A good campus culture can reasonably guide college students' thinking mode, life attitude, style of handling things and moral norms in a subtle way, and has a positive effect on shaping correct values of college students.

2) Inheritance: College campus culture not only mirrors the times of socialism with Chinese characteristics, but also inherits the fine cultural traditions of the Chinese nation. As a carrier of knowledge inheritance, colleges and universities pass on the essence of excellent classical culture from generation to generation through the historical accumulation of universities, teachers' words and deeds, and students' interaction and communication to form distinctive school 
spirit, learning style, thinking mode and values, influencing generation after generation.

3) Encouragement: The campus cultural atmosphere with mutual assistance and competition helps to enhance college students' desire for knowledge, and they can actively enrich all aspects of knowledge in the competition, and make clear the goals to be achieved and strive for them in the exchange. Competitive projects in cultural activities can effectively boost students' sense of self-respect and honor, and promote the development of students' combatant spirit.

4) Cohesion: From the micro perspective, all kinds of cultural activities on campus are collective activities, which make for the cultivation of team consciousness and cooperative spirit of college students. From the macro perspective, common values and a good campus atmosphere can strengthen college students' sense of responsibility, honor and belonging, and motivate their vigor and passion, so that they can work together for university's development goals.

\section{DRAGON BOAT SPORT AND CONSTRUCTION OF College CAmpus Culture}

\section{A. Dragon Boat Sport and Its Culture}

Dragon boat sport is the body-building event of traditional folk custom of Chinese nation, and it arose in the Han dynasty with a history of more than two thousand years. Dragon boat sport is deeply rooted in the Chinese "dragon" culture, and the prow and stern of each boat are respectively engraved with magnificently decorated dragon's head and tail, and quant represents the dragon's claws. So to speak, dragon boat sport is a kind of pattern of manifestation of Chinese dragon culture and dragon boat culture. In the long process of inheritance, dragon boat sport gradually integrates culture, entertainment and athletics, and combines with the commemoration of heroic figures. It has formed a kind of special spirit and character in the constant improvement and sublimation.

The spirit essence of dragon boat sport can be generalized as the following four aspects:

1) Inheritance of national culture: National festival is an important carrier of inheriting national culture, and bears the historical accumulation of national spirit and is the selfexpression of national appearance. As the traditional festival activity of Dragon Boat Festival, dragon boat sport is the main form of inheriting national spirit and shows the collective wisdom of Chinese nation. The culture symbol of "solidarity and cooperation, striving and helping each other in the same boat" it has revealed is the core value of Chinese nation.

2) Establishment of patriotism: Dragon boat sport is the movement that commemorates Qu Yuan, a patriotic poet. The deeds of $\mathrm{Qu}$ Yuan endow the dragon boat sport with patriotic and civilian-cared feelings, and our respect and commemoration for him show our love for our country and nation. It can be said that the process of dragon boat sport we are engaged in is the process that we receive patriotism education. The sincere patriotic feeling reflected by dragon boat culture encourages people to learn the rhadamanthine character and persevering national integrity.

3) Training of volitional quality: Dragon boat sport needs a strong will and the spirit of not giving up. Dragon boat sport event has no direct physical confrontation, to a certain extent, it is the contest that the sportsman competes with himself and farthest excavates their own potential, which is the great test for perseverance and physical ability. Whether it is in the learning of technical movement and exercise of physical quality in the training, or the struggle of breaking the limits in the contest, it needs the persistent willpower to support.

4) Consciousness of solidarity and cooperation: Dragon boat sport is a group event. In the involvement process, team members should paddle together under the unified order of drummer, when giving full play of their personal power, they should completely support the rhythm of their partners and drummer. Only when three (four) men of helmsman, drummer (batter) and boatman are in step can they achieve the unanimous frequency and action. The special features of dragon boat sport effectively stimulate the member's team spirit and improve their collaboration ability.

\section{B. The Influence of Developing Dragon Boat Sport on College Campus Culture}

1) Inheriting dragon boat culture and carrying forward national spirit: Colleges and universities are the important carriers of cultural inheritance. In colleges and universities, there are not only leaders of cultural inheritance, but also inheritors of cultural inheritance, so that the excellent traditional culture can be passed down from generation to generation. Dragon boat culture is an important part of China's excellent traditional culture, and inextricably linked with China's traditional festival culture, folk culture and religious culture. Carrying out dragon boat sport in colleges and universities and popularizing the spirit essence of dragon boat culture are important measures to promote national culture and enhance students' national self-confidence and sense of pride.

2) Enhancing students' collective consciousness and cultivating their teaming and collaboration ability: Organizing and participating in dragon boat events in colleges and universities can enhance students' cohesiveness and centripetal force, make them deeply realize that they are a member of this team and can receive education and enhance their abilities, and cultivate a sense of collectivism. At the same time, the combination of dragon boat culture and university spirit is conducive to college students establishing common ideal goals, and makes the college form an inspiring environment of racing each other and good atmosphere of full of youthful spirit, soaring spirit and forging ahead.

3) Training students' willpower and character and enhancing cultural and educational exchanges: Hundreds of boats competing with each other and marching forward courageously will be inevitably seen in the dragon boat events. Compared with other campus cultural activities, dragon boat 
sports have their own unique charm, that is, the coexistence of inheritance, competitiveness and entertainment and strong attraction and cohesion. Both competitors and viewers are attracted by the fierce competition atmosphere. This active atmosphere can effectively promote interpersonal communication and enhance friendship and affection. At the same time, the dragon boat events reflect the spirit of never giving up and the quality of daring to compete and struggle with each other, and breaking their own the limits, which is an indispensable part for the study and life of college students. It can be said that the dragon boat sport not only provides a platform for college students to know and exchange with each other, but also shows young people's spirit of the time of young blood, forging ahead in unity and fighting spirit.

4) Enriching campus life and improving the radiation function of campus culture: With the extensive development of college dragon boat sports, various friendly matches, competitions, and learning and communication activities have emerged, which not only deepens the understanding and interaction among students, but also enhances the cultural exchanges and cooperation between universities In the meantime, some colleges and universities have planned activities of dragon boat culture exchange with neighboring enterprises and communities. These activities not only show the competitive level and spiritual outlook of university dragon boat team, but also gradually increase the breadth and depth of communication with enterprises and communities. These activities will become a source of radiation, which can greatly improve and enhance the radiation function of the campus culture.

\section{The DeVElopment Status of Dragon BoAt SPORT IN COLlEGE AND UNIVERSITIES — A CASE STUdy OF WuHAN BUSINESS UNIVERSITY}

Wuhan Business University is the vice-chairman unit of Federation of University Sports of China Rowing and Dragon Boat Branch, as well as a training base of dragon boat in Hubei Province. It has been awarded the title of "excellent university" by Federation of University Sports of China Rowing and Dragon Boat Branch. Dragon boat team of Wuhan Business University, founded in 2008, is a well-known strong team in Hubei province. It has taken part in the national dragon boat race on many occasions on behalf of Wuhan City and Hubei Province. In recent years, the university dragon boat team has reached a cooperation agreement with the Seaside City, and the standard pier and base for dragon boat training by the Houguan Lake beside the Seaside City have been established.

In order to further understand college students' cognition of dragon boat culture and sport, we have conducted a questionnaire survey on students of Wuhan Business University to find out the problems and shortcomings in the inheritance of dragon boat culture and the promotion of dragon boat sport from the point to the surface.

TABLE I. INVESTIGATION ON THE UNDERSTANDING OF DRAGON BOAT Culture

\begin{tabular}{|c|l|l|l|}
\hline & $\begin{array}{c}\text { Understand } \\
\text { part of content }\end{array}$ & $\begin{array}{c}\text { Do not } \\
\text { understand } \\
\text { the content }\end{array}$ & $\begin{array}{c}\text { Show great } \\
\text { concern }\end{array}$ \\
\hline $\begin{array}{c}\text { Number of } \\
\text { Students }\end{array}$ & 105 & 68 & 37 \\
\hline Percentage & 52.3 & 30.9 & 16.8 \\
\hline
\end{tabular}

We can see from "Table I" that among the 220 students surveyed, 115 students have certain understanding of dragon boat culture, accounting for $52.3 \%$ of the total; 68 students do not understand it, accounting for $30.9 \%$ of the total; only 37 students show great concern about it, accounting for $16.8 \%$ of the total. It can be seen from the data that as a dragon boat sport carrying excellent traditional history and culture, its cultural connotation has not been understood and concerned by most students.

TABLE II. INVESTIGATION ON DRAGON BOAT SPORT

\begin{tabular}{|l|l|l|l|l|l|}
\hline $\begin{array}{c}\text { Do you understand } \\
\text { the basic composition } \\
\text { of dragon boat? }\end{array}$ & \multicolumn{2}{c|}{$\begin{array}{c}\text { Have you ever } \\
\text { watched dragon boat } \\
\text { events on the spot? }\end{array}$} & $\begin{array}{c}\text { Have you ever } \\
\text { experienced dragon } \\
\text { boat sport? }\end{array}$ \\
\hline Yes & $38.6 \%$ & Yes & $15.9 \%$ & Yes & $3 \%$ \\
\hline No & $61.4 \%$ & No & $84.1 \%$ & No & $97 \%$ \\
\hline
\end{tabular}

As can be seen from "Table II", among the 220 students surveyed, 135 students do not understand the basic situation of dragon boat including its composition, number and rule, accounting for $61.4 \%$ of the total; only 35 students have watched dragon boat races on the spot and only 7 students have experienced dragon boat sport, respectively accounting for $15.9 \%$ and $3 \%$ of the total. What is clear from the data is that although there is professional dragon boat teams in colleges and universities, proportionately, dragon boat sport has not been popularized, and most people have experienced neither the atmosphere of dragon boat, nor charm of the sport itself, and even some people do not know the basic composition of dragon boat.

TABLE III. InVESTIGATION ON THE PROPAGANDA OF DRAGON BOAT SPORT

\begin{tabular}{|l|l|l|l|l|l|l|l|}
\hline $\begin{array}{c}\text { Does the university } \\
\text { offer dragon boat } \\
\text { courses? }\end{array}$ & \multicolumn{2}{|c|}{$\begin{array}{c}\text { Is there a dragon } \\
\text { boat association in } \\
\text { the university? }\end{array}$} & \multicolumn{2}{c|}{$\begin{array}{c}\text { Have you ever } \\
\text { visited the dragon } \\
\text { boat team? }\end{array}$} & \multicolumn{2}{c|}{$\begin{array}{c}\text { Are you concerned about } \\
\text { the dragon boat dual meet? }\end{array}$} \\
\hline Yes & $0 \%$ & Yes & $0 \%$ & Yes & $1.4 \%$ & Yes & $20.9 \%$ \\
\hline No & $46.4 \%$ & No & $71.4 \%$ & No & $65.9 \%$ & No & $48.2 \%$ \\
\hline Unclear & $53.6 \%$ & Unclear & $28.6 \%$ & Unclear & $32.7 \%$ & Heard of it & $30.9 \%$ \\
\hline
\end{tabular}

"Table III" shows that Wuhan Business University has not yet offered dragon boat courses, established dragon boat association and conducted dragon boat activities. Among the 220 students surveyed, only 3 students have visited the dragon 
boat training, accounting for $1.4 \%$ of the total; 145 students haven't been to the dragon boat training ground, accounting for $65.9 \%$ of the total; 72 students haven't heard of the dragon boat team in university, accounting for $32.7 \%$ of the total. For the dragon boat dual meet, only 46 students say they concern about it, and nearly half of them pay no attention to it, and 68 students have only heard of it, accounting for $30.9 \%$ of the total. It can be seen from the data that the publicity and promotion of dragon boat sport in colleges and universities are still far from enough. Most students do not participate in it, and some students are indifferent to it.

This shows that there are still some problems in the development of dragon boat sport in colleges and universities, such as low participation, insufficient publicity and lack of understanding of cultural connotation of dragon boat. The dragon boat sport has not yet become an important part of the construction of college campus culture. In view of the existing problems, we need to make a study and put forward some specific measures, take dragon boat culture as the carrier, integrate other cultural resources of colleges and universities, and boost the organic fusion of dragon boat sport and campus culture.

\section{PROMOTING THE INTEGRATIVE DEVELOPMENT OF COllege Dragon BoAt SPORT AND CAMPUS CUlture}

\section{A. Enhancing the Propaganda of Dragon Boat Culture}

1) Holding cultural festivals of dragon boat in colleges and universities: We will organize and conduct dragon boat seminar and dragon culture writing competition, and encourage students to actively participate in them, so as to form the atmosphere of carrying forward spirit of patriotism and inspiring them to conduct research on traditional culture.

2) Carrying out practical activities themed with dragon boat: Before and after the Dragon Boat Festival, we will conduct the practical activities themed with dragon boat, provide some interesting games, such as tug of war, guessing, relay race and making the finishing point related to dragon boat when people experience the dragon boat sport on the river, and integrate the cultural element of Dragon Boat Festival including competition of making rice dumplings, to make college students experience the spirit of dragon boat culture and pleasure of solidarity and cooperation in the entertainment.

\section{B. Relying on the Dragon Boat Association to Promote Dragon Boat Culture and Sport}

1) Establishing dragon boat association: We will organize the students to establish dragon boat association in the college and recruit new members in October of every year. The new member should not only include students in the school of physical education, but also cover other students who are non-physical major students but love dragon boat events.

2) Exploring dragon boat cultural exchange among colleges and universities: We will rely on dragon boat association to carry out multiform cultural exchange activities, such as knowledge contest, events competition, skill competition and experience forum, take "dragon" to make friends and make the dragon boat become the bond of cultural exchange among colleges and universities.

\section{Participating in Dragon Boat Events at Each Level}

We will actively promote the dragon boat team to participate in professional competitions at national and provincial level, and run regional college dragon boat competitions, showing the spirit of the university and the dragon boat in the competition. Besides, we will organize students to watch the dragon boat events on the spot, better feel the passion of dragon boat events and the charm of dragon boat culture, and communicate with different universities, different grades and students in different majors to enrich their spare time life and form a cultural atmosphere of unity, cooperation and mutual help.

\section{Offering Elective Course of Dragon Boat}

We will put the inheritance and promotion of dragon boat culture as an important part of the campus culture construction of colleges and universities. Through the establishment of dragon boat elective courses, the knowledge of dragon boat culture is popularized. The course teaching can be divided into two parts: theory and practice. Theoretical part includes the origin of dragon boat, development history and cultural connotation of dragon boat sport, and main rules of competitive races. The practical part includes the action essentials and training methods of drummers, helmsmen and paddlers.

Through the implementation of dragon boat cultural activities, we can inherit dragon boat culture, increase cohesion and form positive "spirit" of university, so as to further the combination of style of study and college and make it integrate into the education atmosphere of colleges. A cooperative consciousness of solidarity and cooperation being united as one and staying in the same boat and a dauntless spirit of tenaciously striving to succeed and being the first can be fostered among students.

\section{CONCLUSION}

The connotation of college campus culture is the sum of the behavioral norms, moral constraints, value orientation, spiritual pillars and life concepts that college students create, follow and share in the long-term education, study, life and practice. Good and healthy college campus culture is conducive to the development of physical and psychological health of college students.

Dragon boat sport has a history of more than two thousand years and is a national traditional sport event in China. The development and promotion of dragon boat sport in colleges and universities can not only inherit and carry forward this sport events, but also make the traditional culture of our country be spread and publicized.

According to the questionnaire survey, we can see that college students in China are more interested in the dragon boat sport, but there are fewer ways for them to understand and participate in the sport. 
We should encourage colleges and universities to establish dragon boat courses, dragon boat associations, dragon boat events and other activities to allow college students to participate in the dragon boat movement, inherit the dragon boat culture, and gather people's hearts.

\section{REFERENCES}

[1] Wei Tao. The Composition, Value Creation Function and Remodeling Strategy of Campus Culture in Colleges and Universities [J]. Economic Research Guide, 2016 (5): 21-24. (in Chinese)

[2] Xu Zhijuan. Research on the Influences of Developing Dragon Boat Sport on Campus Culture [J]. Journal of Hubei Sports Science, 2011 (3): 46-54. (in Chinese)

[3] Li Xiaofei. Investigation and Research on the Status Quo of Dragon Boat Sport in Hubei Province [M]. School of Physical Education, Central China Normal University, 2013. 5. (in Chinese)

[4] Li Bing. Research on the Influence of Dragon Boat Sport in Colleges and University on the Inheritance of Dragon Boat Culture [J]. Times Literary, 2010 (6): 41-45. (in Chinese) 